\title{
EVALUATION OF THE AUTUMN INFECTION OF WINTER BARLEY WITH BARLEY YELLOW DWARF VIRUSES TRANSMITTED BY ANHOLOCYCLIC FORMS OF BIRD CHERRY- OAT APHID RHOPALOSIPHUM PADI L. IN POLAND
}

\author{
Przemysław Strażyński, Maria Ruszkowska*, Małgorzata Jeżewska, Katarzyna Trzmiel
}

Institute of Plant Protection - National Research Institute

Władysława Węgorka 20, 60-318 Poznań, Poland

Received: February 9, 2011

Accepted: June 8, 2011

\begin{abstract}
Research was carried out to determine the extent of anholocyclic forms of bird cherry-oat aphid, Rhopalosiphum padi on winter barley, and to estimate the level of infection of winter barley crops with Barley yellow dwarf (BYD) viruses. Observations were made in 12 Polish regions. Each region is made up of four distinct locations, with different temperatures. The 12 observed regions were: Lubuskie, Dolnośląskie, Opolskie, Śląskie, Małopolskie, Podkarpackie, Wielkopolskie, Łódzkie, Mazowieckie, Lubelskie, Warmińsko-Mazurskie and Podlaskie. The research was carried out during the period of colonization of plants by aphids. Anholocyclic forms of $R$. padi were found on winter barley crops in all regions, with the exception of the Podlaskie area. Samples of plants were collected and tested for virus occurrence by ELISA. In 2007, the detection of BYD viruses in aphids feeding on winter barley was performed using the PCR technique. Virus diagnostics revealed the prevalence of Barley yellow dwarf virus-PAV (BYDV-PAV) over Barley yellow dwarf virus-MAV (BYDV-MAV), in 2006 and 2007. Aphid vectors of BYD viruses were the most numerous in all the locations of the Opolskie region.
\end{abstract}

Key words: aphids, Rhopalosiphum padi, barley yellow dwarf viruses

\section{INTRODUCTION}

Recently in Poland an increase in the number of aphids infesting cereals has been observed. The diversity of species and forms of aphids, the ability to migrate, and the quick adaptation-reaction to any environmental changes, mean these insects are becoming increasingly important in plant protection (Leszczyński 1985; Ruszkowska 1988, 1990a, b 2002; Eastop 1995; Dixon 1998; Giebel et al. 1998; Martinez-Torrez et al. 1997; Mrówczyński et al. 2004). One of the factors causing new potential threats to cereals is the higher temperature in some regions of Poland, which switch the holo- into anholo- life cycle. High temperatures during spring and summer are necessary for the development of anholocyclic forms of cereal aphids in the natural environment. Temperature monitoring is a key element in the projection of these important developmental changes of aphids. A few days of temperature $\geq 25^{\circ} \mathrm{C}$ will induce the development of these forms in the spring and summer. Temperature $\geq 25^{\circ} \mathrm{C}$ is the first sign of the possibility of the presence of cereal virus infection (Ruszkowska 1998, 2002, 2006, 2007a, b; Ruszkowska and Strażyński 2007). The dominating species among cereal aphids in Poland is the bird cherry-oat aphid (Rhopalosiphum padi L.) and anholocyclic forms of this species are the most important vectors of BYDV (Jeżewska et al. 2010).
Aphid vectors of plant viruses may play an important role in the epidemiology of certain diseases, such as Barley yellow dwarf (BYD). Symptoms of BYD are caused by several small spherical viruses transmitted exclusively by aphids in a persistent manner (Plumb 1992; Power et al. 1991). The main causal agents of BYD in Poland are: Barley yellow dwarf virus-MAV (BYDV-MAV), Barley yellow dwarf virus-PAV (BYDV-PAV and Cereal yellow dwarf virus$R P V$ (CYDV-RPV). BYD previously did not have a significant economic impact on the yield of cereals in Poland. Nowadays however, BYD is considered to be a serious potential danger particularly for winter barley crops. The economic importance of BYD associated with the increase of anholocyclic aphid populations was reported (BadilloVargas and Gildow 2004; Lowles et al. 1999).

The common presence of $R$. padi on winter cereals enhances the potential danger of early infections with BYD viruses (Strażyński 2010). The increase of BYD occurrence in recent years was recorded (Jeżewska 2003; Jeżewska et al. 2010).

Therefore, in the years 2006-2008, studies were undertaken in order to recognize the structure of the population of $R$. padi, depending on the temperatures in different regions of the country. An additional objective was to check the impact of the occurrence of anholocyclic forms 
of $R$. padi on the autumnal infections of winter barley plants with BYD viruses.

The first aim of our study was to provide an update on the proportions of anholocyclic forms of $R$. padi conditioned by proper temperature. The second aim of our study was to determine the dynamics of changes in the diversity of forms and morphs.

\section{MATERIALS AND METHODS}

\section{Entomological research}

The study was conducted in 2006-2008, to determine the territorial range of anholocyclic forms of R. padi. Observations were made in twelve Polish regions, all with different temperatures: Dolnośląskie, Lubelskie, Lubuskie, Łódzkie, Małopolskie, Mazowieckie, Opolskie, Podkarpackie, Podlaskie, Śląskie, Warmińsko-Mazurskie and Wielkopolskie.

Studies for the presence of anholocyclic forms were conducted during the summer (harvest maturity) and autumn (after emergence of cereals). These forms infesting mature cereals were identified on the basis of the mode of plant colonization. Anholocyclic R. padi preferred to inhabit lower parts of stalks, just off the ground, while holocyclic forms fed on the upper parts of the plants.

Observations were carried out on 4 fields in different locations following the diagonal, each time on 100 plants selected at random. Similar observations were carried out in autumn from the emergence to the onset of $-6^{\circ} \mathrm{C}$ temperature, which is a critical temperature for aphid development. The specificity of spatial colonization of cereals within the entire crop had to be taken into account in the field observations (Dean 1970).

Throughout the period of the research, the course of the temperatures in all locations was monitored using a web application Weatherscope (http//weatherscope. com). The collected data was analyzed in terms of sums of daily average temperature; the number of days per year with average daily temperature $\geq 25^{\circ} \mathrm{C}$.

\section{Virus diagnostics}

\section{Materials}

The detection of BYD viruses was carried out in plants and aphids.

\section{Plants}

Plant samples were mainly winter barley plants infested with aphids, collected in fields during autumn inspections in different regions of Poland. Occasionally, samples of wild grasses were collected for tests, too. The collection of samples was performed as follows:

- in each region of inspection five locations were chosen, distanced at least $20 \mathrm{~km}$ from each other,

- in each field five samples were taken and each sample consisted of ten leaves,

- wild grass species for analyses included Dactylis glomerata, Poa annua, Setaria viridis) and Elymus regens.

\section{Aphids}

R. padi aphids tested for the presence of BYD viruses were collected on winter barley fields in autumn.

\section{Methods}

Preparation of plant samples for virus diagnostics

Plant samples were placed in climatic chambers at $20^{\circ} \mathrm{C}$, with $70 \%$ humidity and $12 \mathrm{hr}$ daylight.

Assessment of the infectivity of aphids as vectors of BYD viruses

Aphids were reared in the conditions described above, to obtain a higher virus concentration and an increase in vector population. At the same time, in the same conditions, the seedlings of winter barley cv. Tiffany were inhabited by part of the same aphid population which migrated in a natural way from field plants. The plants were sown into 8 pots of $17 \mathrm{~cm}$ diameter, 20 seeds in each pot. After three weeks, aphids and plants were taken for virus diagnostics.

\section{The detection of BYD viruses}

For routine diagnostics of BYD viruses in plants, the ELISA test was used (Clark and Adams 1977). Commercial immunoglobulins and conjugates were provided by Loewe (Germany) and Adgen (Neogen) (UK). In the years 2006 and 2007, the assays were performed for only two BYD causal agents which were: BYDV-MAV and BYDVPAV, and in 2008 CYDV-RPV was also included.

The molecular method of reverse transcription - polymerase chain reaction (RT-PCR) was also applied as a reference diagnostic test for the detection of BYD viruses in plants and aphids.

The detection of the viruses in aphids was carried out: directly using RT-PCR, and indirectly by feeding the field aphids on healthy plants and testing the plants after the period of incubation (minimum 3 weeks), by ELISA.

\section{Molecular detection of BYD viruses}

Total RNA isolation from about $120 \mathrm{mg}$ of plant material or about 10 aphids was carried out with the use of the RNeasy Mini Kit (Qiagen), according to the procedure description supplied by the producer. The RNA was eluted with $40 \mu \mathrm{l}$ RNase-free water. One- step RT-PCR kit (Qiagen, Germany), with literature primers Lu 1 and Lu 4 (Robertson et al., 1991) and with M3 and M4 (Biskiens et al. 2004), was used to confirm the presence of BYDVPAV and BYDV-MAV, respectively. Lu1/Lu4 and M3/ M4 primer pairs amplified $531 \mathrm{bp}$ and $650 \mathrm{bp}$ fragment of coat protein of the studied viruses. The primers Act1/ Act2 amplified $320 \mathrm{bp}$ fragment of a conserved region of insect actin (Canning et al. 1996), were applied as an internal control for virus detection in aphids. RT-PCR was carried out in total $10 \mu \mathrm{l}$ volume containing: $1 \mu \mathrm{l}$ template RNA, $1 \mu \mathrm{l}$ forward and $1 \mu \mathrm{l}$ reverse primers $(10 \mu \mathrm{M})$, $2 \mu l 5$ x Qiagen OneStep RT-PCR Buffer, 0,4 $\mu$ l dNTP Mix $(10 \mathrm{mM}), 0,4 \mu \mathrm{l}$ Qiagen OneStep RT-PCR Enzyme Mix, 10 units of RiboLock RNase inhibitor (Fermentas). BYDV-MAV detection included: a reverse transcription for $30 \mathrm{~min}$ at $50^{\circ} \mathrm{C}$ and an initial PCR activation step for 
$15 \mathrm{~min}$ at $95^{\circ} \mathrm{C}$ and $2 \mathrm{~min}$ at $94^{\circ} \mathrm{C}$, followed by 35 cycles including denaturation for $30 \mathrm{sec}$ at $94^{\circ} \mathrm{C}$, annealing for $30 \mathrm{sec}$ at $55^{\circ} \mathrm{C}$ and elongation for $90 \mathrm{sec}$ at $72^{\circ} \mathrm{C}$. A final elongation was completed at $72^{\circ} \mathrm{C}$ for 10 minutes. BYDVPAV detection was performed as follows: after a reverse transcription for $30 \mathrm{~min}$ at $50^{\circ} \mathrm{C}$ and an initial PCR activation step for $15 \mathrm{~min}$ at $95^{\circ} \mathrm{C}, 35$ cycles including denaturation for $45 \mathrm{sec}$ at $94^{\circ} \mathrm{C}$, annealing for $1 \mathrm{~min}$ at $59^{\circ} \mathrm{C}$ and elongation for $1 \mathrm{~min}$ at $72^{\circ} \mathrm{C}$, and a final elongation at $72^{\circ} \mathrm{C}$ for 10 minutes, were carried out.

RT-PCR products were separated electrophoretically in $1 \%$ agarose gel and visualised in UV after staining with ethidium bromide.
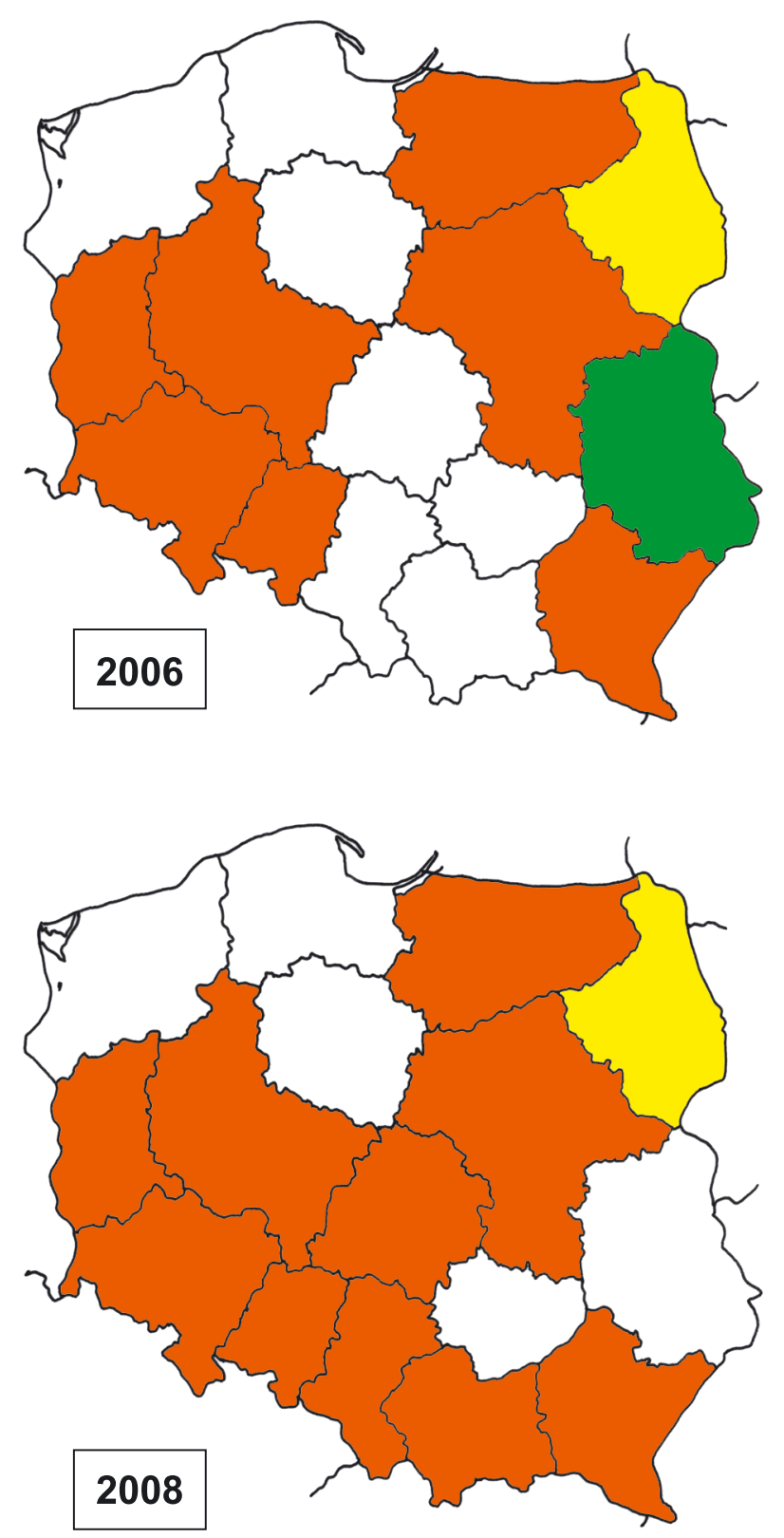

\section{RESULTS}

Aphids on winter cereals in the field observations

The numbers of anholocyclic forms registered on winter barley in the summer is presented in table 1 . In most locations, the aphids were found in clusters at the edges of crops, very rarely in the depth of field. The greatest abundance of anholocyclic R. padi were found in July 2006, in the regions of Opolskie and Wielkopolska. The least numerous forms of these occurred in 2006-2007, on crops in the Warmińsko-Mazurskie region.

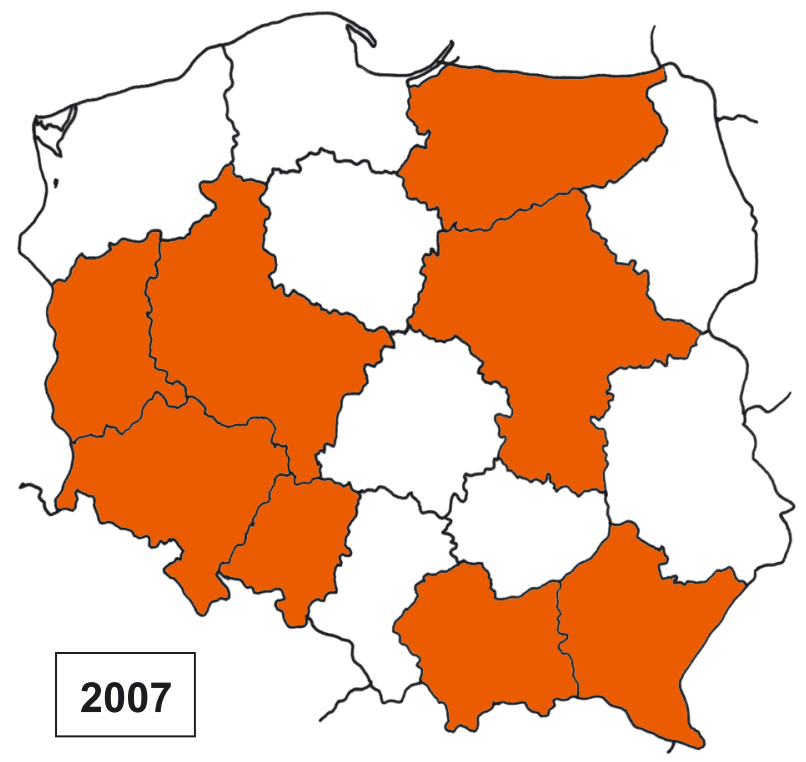

Aphids on winter barley, BYDV presence

Aphids on winter barley, no BYDV presence

No aphids on winter barley, no BYDV presence

Areas not covered by the observations

Fig. 1. R. padi on winter barley in autumn and BYDV presence in 2006-2008, in Poland

In 2006-2008, in climatically diverse regions of Poland, the autumnal winter cereal crops were observed for the presence of aphids feeding on plants, and the degree of infection by BYD viruses. The territorial expansion of anholocyclic R. padi and BYD is shown in figure 1. 
Table 1. Anholocyclic forms of R. padi on winter barley at maturity stage in the years 2006-2008, in the studied regions

\begin{tabular}{|l|c|c|c|c|}
\hline \multirow{2}{*}{ Term of observation } & \multirow{2}{*}{ Region } & \multicolumn{3}{|c|}{ Number of anholocyclic forms on mature plants* } \\
\cline { 2 - 5 } & & 2006 & 2007 \\
\hline July & Wielkopolskie & 68 & 11 & 26 \\
\hline July & Opolskie & 70 & 21 & 48 \\
\hline August & Wielkopolskie & 38 & 12 & 34 \\
\hline August & Warmińsko-Mazurskie & 23 & 16 & 46 \\
\hline August & Podkarpackie & 42 & 32 \\
\hline
\end{tabular}

*average from 100 plants from 4 fields

In 2006, the observations were performed in nine regions: Lubuskie, Wielkopolskie, Dolnośląskie, Opolskie, Podkarpackie, Lubelskie, Mazowieckie, Podlaskie and Warmińsko-Mazurskie. The occurrence of aphids in winter crops and the simultaneous infection of BYD viruses was found in 7 of them: Lubuskie, Wielkopolskie, Dolnośląskie, Opolskie, Warmińsko-Mazurskie, Mazowieckie and Podkarpackie. In the Lubelskie region, aphids were observed on winter crops, but the plants were not infected by viruses. In 2006, in the Podlaskie region, there were no aphids colonizing winter crops and no infected plants.

In 2007, the observations were carried out in the regions of Lubuskie, Wielkopolskie, Dolnośląskie, Opolskie, Małopolskie, Podkarpackie, Mazowieckie and Warmińsko-Mazurskie. All aphids found on winter bar- ley were vectors of BYDV in every region covered by our observations.

In 2008, observations were made in the same areas as in 2007, but the observations were extended into the following regions: Łódzkie, Małopolskie and Podlaskie. In the Podlaskie region, as in 2006, there were no aphids on winter crops and no infected plants. In the remaining regions, aphids settling winter cereals as well as infection of plants were registered.

\section{Temperature in the studied regions inducing the develop-} ment of anholocyclic forms of aphids

Table 2 shows the number of days with the mean daily temperature which induces the development of anholocyclic forms of R. padi, $\geq 25^{\circ} \mathrm{C}$.

Table 2. Temperature switching development of the anholocyclic R. padi in the years 2006-2008, in selected regions of Poland

\begin{tabular}{|l|c|c|c|c|c|c|}
\hline \multirow{2}{*}{ Region } & \multicolumn{2}{|c|}{2006} & \multicolumn{2}{c|}{2007} & \multicolumn{2}{c|}{2008} \\
\cline { 2 - 7 } & $\begin{array}{c}\text { number of } \\
\text { days with } \\
\text { temperature } \\
\geq 25^{\circ} \mathrm{C}\end{array}$ & $\begin{array}{c}\text { date of first } \\
\text { day with an } \\
\text { average daily } \\
\geq 25^{\circ} \mathrm{C}\end{array}$ & $\begin{array}{c}\text { number of } \\
\text { days with } \\
\text { temperature } \\
\geq 25^{\circ} \mathrm{C}\end{array}$ & $\begin{array}{c}\text { date of first } \\
\text { day with an } \\
\text { average daily } \\
\geq 25^{\circ} \mathrm{C}\end{array}$ & $\begin{array}{c}\text { number of } \\
\text { days with } \\
\text { temperature } \\
\geq 25^{\circ} \mathrm{C}\end{array}$ & $\begin{array}{c}\text { date of first } \\
\text { day with an } \\
\text { average daily } \\
\geq 25^{\circ} \mathrm{C}\end{array}$ \\
\hline Wielkopolskie & 17 & 7.07 & 6 & 15.07 & 7 & 10.08 \\
\hline Opolskie & 14 & 25.06 & 20 & 24.05 & 9 & 11.08 \\
\hline Warmińsko-Mazurskie & 5 & 29.06 & 3 & 21.06 & 2 & 18.06 \\
\hline Podkarpackie & 2 & 18.06 & 6 & 14.06 & 10 & 18.06 \\
\hline
\end{tabular}

In the region of Wielkopolska (Poznań), in each year of observation, the occurrence of temperatures conditioning the development of these forms has been reported. This situation has been recorded continuously since 1999 (Ruszkowska 2007a). In 2007, in Opole (the Opolskie region), up to 20 days with a daily mean temperature of $\geq$ $25^{\circ} \mathrm{C}$ were recorded, which took place after 25 May.

In 2006, in the Warmińsko-Mazurskie region there were 5 days with temperatures $\geq 25^{\circ} \mathrm{C}$, while for the first time in this region the occurrence of the infectious $R$. padi was recorded. Until then, among all the regions selected for study, no anholocyclic forms were found outside of the Podlaskie region.

\section{The detection of $B Y D$ viruses}

\section{Detection of viruses in plants collected in fields}

Results of the detection of BYD viruses in winter barley plants infested with aphids in the years 2006-2008, are presented in the table 3 . In ELISA tests, the OD value in positive samples ranged from 0.1 to 0.9 . In the case of a low virus concentration, where the results obtained in ELISA tests were doubtful, the molecular technique of RT-PCR was applied as a reference diagnostic method. Single RT-PCR products of the expected sizes: about 530 $\mathrm{bp}$ and $650 \mathrm{bp}$, respectively, from BYDV-PAV and BYDVMAV infected plants were obtained (Figs. 2, 3). 
Table 3. Detection of barley yellow dwarf viruses in winter barley plants collected in different regions of Poland in the years 2006-2008

\begin{tabular}{|c|c|c|c|}
\hline \multirow{2}{*}{$\begin{array}{c}\text { Region and the date of } \\
\text { sampling }\end{array}$} & \multicolumn{3}{|c|}{ Detection of viruses by ELISA (number of plants found infected/ number of plants tested) } \\
\hline & BYDV-MAV & BYDV-PAV & CYDV-RPV \\
\hline \multicolumn{4}{|c|}{2006} \\
\hline Opolskie, 26.10 & $0 / 21$ & $8 / 21$ & - \\
\hline Lubuskie, 12.11 & $0 / 12$ & $12 / 12$ & - \\
\hline Podkarpackie, 22.11 & $1 / 16$ & $2 / 16$ & - \\
\hline \multicolumn{4}{|c|}{2007} \\
\hline Opolskie, 18.10 & $0 / 25$ & $21 / 25$ & - \\
\hline Warmińsko-Mazurskie, 13.11 & $0 / 25$ & $15 / 25$ & - \\
\hline Podkarpackie, 22.11 & $4 / 25$ & $7 / 25$ & - \\
\hline Wielkopolskie, 3.12 & $0 / 25$ & $5 / 25$ & - \\
\hline Małopolskie, 6.12 & $2 / 25$ & $14 / 25$ & \\
\hline \multicolumn{4}{|c|}{2008} \\
\hline Opolskie, 4.04 & $11 / 25$ & $5 / 25$ & $8 / 25$ \\
\hline Wielkopolskie, 20.10 & $0 / 16$ & $11 / 16$ & $0 / 16$ \\
\hline Lubuskie, 23.11 & $2 / 16$ & $4 / 16$ & $0 / 16$ \\
\hline Łódzkie, 7.11 & $11 / 32$ & $14 / 32$ & $7 / 32$ \\
\hline Lubuskie, 13.11 & $1 / 32$ & $32 / 32$ & $1 / 32$ \\
\hline
\end{tabular}

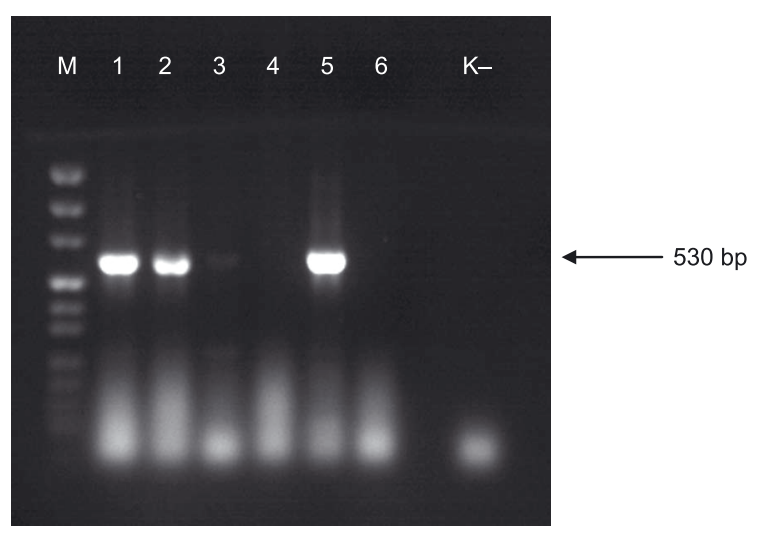

Fig. 2. The detection of BYDV-PAV in barley plants. Electrophoresis of the RT-PCR products using Lu1 and Lu4 primer pairs. M - O'Gene Ruler ${ }^{\mathrm{TM}}$ 100bp DNA Ladder, lanes:1, 2, 3, 4, 5, 6 - plant samples, K- - negative control

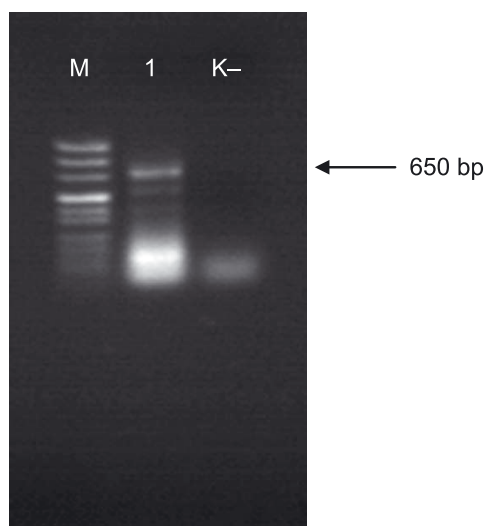

Fig. 3. The detection of BYDV-MAV in barley plants. Electrophoresis of the RT-PCR products using MAV3 and MAV4 primer pairs. M - O'Gene Ruler ${ }^{\mathrm{TM}}$ 100bp DNA Ladder; 1 - plant sample; K- - negative control 
In all the years of our research, the dominating virus in barley fields was BYDV-PAV with the exception of the Opolskie region in spring 2008, when unexpectedly, the predominance of BYDV-MAV was revealed. In 2008, the diagnostics included the third potential causal agent of BYD, CYDV-RPV. The frequency of its occurrence, particularly in the Opolskie region was relatively high. On the basis of such a limited number of plants tested, it was not possible to point out a clear differentiation of the regions regarding the risk of BYD viruses incidence. The disease was encountered everywhere. However, from the obtained data, the most serious risk of BYD occurrence can be assumed to exist in the Opolskie region, where climatic conditions are especially favorable for aphid vectors.

\section{The detection of $B Y D$ viruses in aphids}

BYD viruses were easily detected in aphids using indirect procedures including test plant diagnostics. In each portion of aphids collected in winter barley fields under observation, the vectors of BYD viruses were detected. However, for the procedure applied, it was not possible to point out the proportion of BYD vectors in the general pool of aphids tested.
The direct procedure, RT-PCR, was successfully applied to detect BYDV-MAV and BYDV-PAV in their aphid vectors.

Twenty-five R. padi samples originating from 5 regions: Warmińsko-Mazurskie, Podkarpackie, Wielkopolskie, Dolnośląskie and Małopolskie, were analyzed.

In electrophoretical patterns the RT-PCR products of expected sizes, corresponding to the presence of the viruses and specific for aphids, were observed. Actin primers tested in RT-PCR with RNA from aphid samples, in all cases gave a single 320 bp product. Two distinguishable bands were visualised from viruliferous vectors and only the actin bands were found in the aviruliferous aphid samples. Electrophoresis of RT-PCR using primers sets: Lu1/Lu4 with Act1/Act2 and MAV3/MAV4 with Act1/Act2 were presented (Figs. 3, 4.). The presence of BYDV-MAV were confirmed in: 5 out of 5 tested field samples collected in the Warmińsko-Mazurskie, Podkarpackie, Dolnośląskie and Małopolskie regions, and 4 out of 5 analyzed samples from the Wielkopolskie region. BYDV-PAV was found in all the studied samples from the Dolnośląskie and Małopolskie regions, and 4 out of 5 assayed probes from the Podkarpackie and Wielkopolskie regions. There were no observed aphids originating from the WarmińskoMazurskie region with BYD viruses in their body.

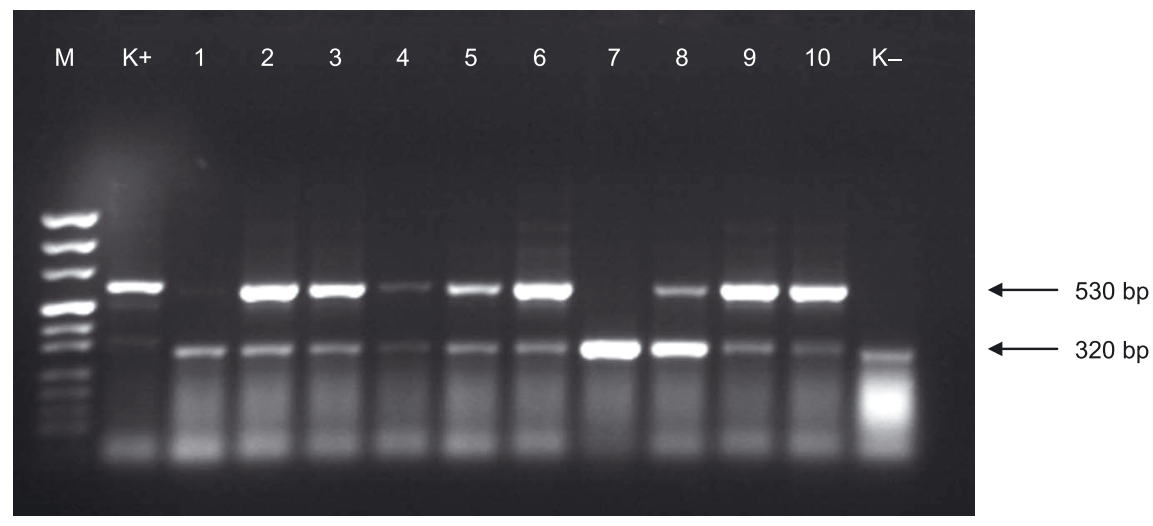

Fig. 4. The detection of BYDV-PAV in aphids. Electrophoresis of the RT-PCR products using Lu1/Lu4 and Act1/Act2 primer sets. M - O'Gene Ruler ${ }^{\mathrm{TM}} 100$ bp DNA Ladder; K+ - positive control (infected aphids); 1, 2 3, 4, 5 - aphid samples from Wielkopolska; 6, 7, 8, 9, 10 - aphid samples from Podkarpackie; K- - negative control, virus free aphids

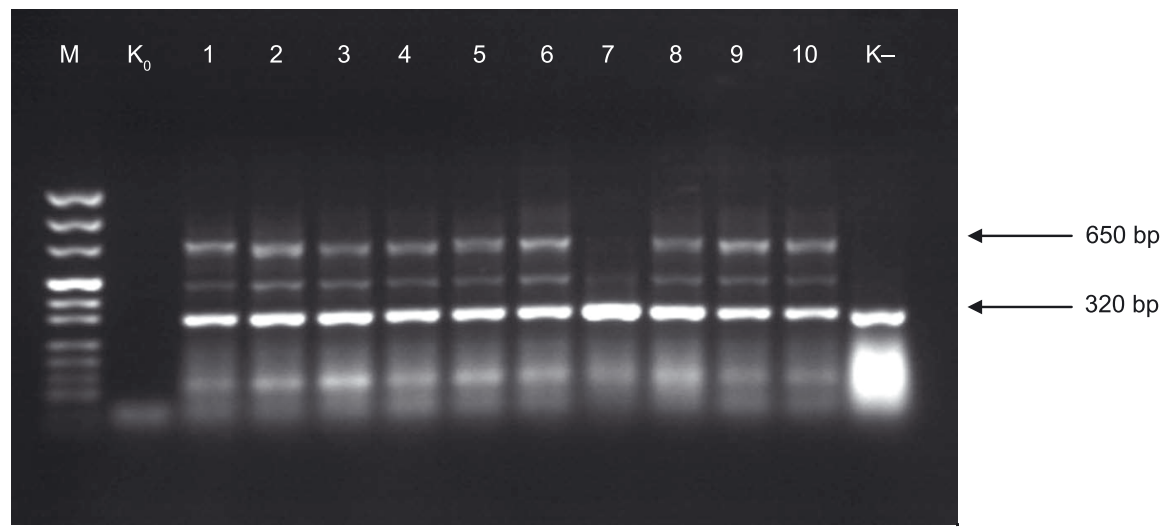

Fig. 5. The detection of BYDV-MAV in aphids. Electrophoresis of the RT-PCR products using MAV3/MAV4 and Act1/Act2 primer sets. M - O'Gene Ruler ${ }^{\mathrm{TM}} 100$ bp DNA Ladder; $\mathrm{K}_{0}$ - water control; 1, 2 3, 4, 5 - aphid samples from Małopolska; $6,7,8,9,10$ - aphid samples from Wielkopolska; K- - negative control, virus free aphids 


\section{DISCUSSION}

The course of temperature during the period of the research allowed for the designation of areas with expected occurrence of aphids on cereal crops - potential vectors of the Barley yellow dwarf viruses. The temperature occurrence which induces a change in aphid life cycle is very important, because the impact of photoperiod after 21 June already prompts the gynoparae development and greatly reduces the development of anholocyclic forms (Ruszkowska 2002).

The development of anholocyclic forms of aphids on winter crops in autumn is possible only under specific temperatures and could be a kind of a bio-indicator of global warming. On the basis of the temperature data, it can be concluded that anholocyclic forms which appear in different years and different regions of Poland, certainly come in large part from the native population. The development of anholocyclic forms is caused by two factors: the high temperature and quality (age) of the host plant (Ruszkowska 2002). On the secondary host, the anholocyclic forms of $R$. padi aphids develop in conditions of respectively high temperatures during spring and summer. In autumn the aphids feed on young plants, and this quality of host plants blocks the return to holocyclic development.

Direction of the territorial expansion of aphids-virus vectors on cereals is closely related to the temperatures in different regions.

The data concerning the detection of BYD viruses in autumn sown barley as well as in aphids infesting the fields are consistent with the data on the evolution of aphid population structure with the systematic increase of the anholocyclic forms (Jeżewska et al. 2010). However, the estimated number of aphids is not the only factor to be considered for the disease prediction. The proportion of aphid vectors of the BYD viruses in the general pool of aphids infesting fields, as well as the climatic conditions, mainly temperature, date of sowing, cultivars, and locations are also important factors for BYD risk predicting (McElphany et al. 1995; Bencharki et al. 2000). The detection of BYD viruses directly in aphids provides valuable information about the potential of infection pressure, provided it would be effective on a proper scale. The results of the research proved that this tool might be taken into account in special needs.

\section{CONCLUSIONS}

1. The development of anholocyclic forms of bird cherry-oat aphid, the main vector of barley yellow dwarf viruses, was obtained in all the studied regions except for the Podlaskie region.

2. The principal factor enabling the expansion of anholocyclic forms of $R$. padi was the increasing temperature.

3. Only the presence of virus vectors is not enough to prove plant infection. So far, the Polish populations of anholocyclic $R$. padi are only partial vectors, viruses were not found in the bodies of all aphids.

4. Common occurrence of BYD viruses in winter barley in autumn, confirms the risk of the disease which should be controlled.

\section{REFERENCES}

Badillo-Vargas I.E., Gildow F.E. 2004. Transmission Specifity of Luteoviruses through Aphid-vector Interactions. Summer research Opportunities Program. http://forms.gradsch. psu.edu/equity/sroppapers/2004/BadilloIsmaelE.pdf

Bencharki B., El Yamani M., Zaoui D. 2000. Assessment of transmission ability of barley yellow dwarf virus - PAV isolates by different populations of Rhopalosiphum padi and Sitobion avenae. Eur. J. Plant Pathol. 106: 455-464.

Bisnieks M., Kvarnheden A., Sigvald R., Valkonen J.P.T. 2004. Molecular diversity of the coat protein-encoding region of Barley yellow dwarf virus-PAV and Barley yellow dwarf virus-MAV from Latvia and Sweden. Arch. Virol. 149: 843-853.

Canning E.S.G., Penrose M.J., Barker I., Coates D. 1996. Improved detection of barley yellow dwarf virus in single aphids using RT-PCR. J. Virol. Methods 56 (2): 191-197.

Clark M.F., Adams A.N. 1977. Characteristics of the microplate method of enzyme - linked immunosorbent assays. J. Gen. Virol. 34: 475-483.

Crowther J.R. 2001. The ELISA Guidebook. Methods in Molecular Biology. 149, Humane Press, Totowa NJ, 421 pp.

Dean G.J. 1970. Distribution of aphids in cereal crops. Ann. Appl. Biol. 66: 485-496.

Dixon A.F.G. 1998. Resource tracking: mechanism - cyclical parthenogenesis. p. 83-84. In: „Aphid Ecology” (A.F.G. Dixon, ed.). Publisher Chapman and Hall, 300 pp.

Eastop V.F. 1995. Aphids, plants and other organismus. Korean J. Appl. Entomol. 34 (1): 1-8.

Giebel J., Woda-Leśniewska M., Ruszkowska M. 1998. Fenoksykwasy powodują wzrost populacji mszyc zbożowych - biochemiczna przyczyna zjawiska. Prog. Plant Protection/ Post. Orch Roślin 38 (2): 365-368.

Jeżewska M. 2003. Choroby wirusowe zbóż, diagnostyka i występowanie. Prog. Plant Protection/Post. Ochr. Roślin 43 (1): 152-159.

Jeżewska M., Buchowska-Ruszkowska M., Cajza M. 2010. Monitoring i diagnostyka molekularna wirusów zbóż. p. 157186. W: „Ograniczanie Strat w Plonach Roślin Uprawnych z Zachowaniem Bezpieczeństwa Żywności”. (D. Sosnowska, ed.) Inst. Ochr. Roślin - PIB, 284 pp.

Leszczyński B. 1985. Changes in phenols content and metabolism in leaves of susceptible and resistant winter wheat cultivars infested by Rhopalosiphum padi (L.) (Hom., Aphididae). Zeit. Ang. Entomol. 100 (4): 343-348.

Lowles A., Harrington R., Mann J., Banwo O.O. 1999. Beyond the Infectivity Index of Barley Yellow Dwarf Virus. Barley Bull. IOBC/WPRS 19. Available on: http://wheat.pw.usda. gov

Martinez-Torrez D., Devonshire A.L., Williamson M.S. 1997. Molecular studies of knockdown resistance to pyretroids: cloning of domain Il sodium channel gene sequences from insects. Pestic. Sci. 51: 265-270.

McElphany P., Real L.A., Power A.G. 1995. Vector preference and disease dynamics: a study of barley yellow dwarf virus. Ecology 76 (2): 444-457.

Mrówczyński M., Wachowiak H., Pruszyński S. 2004. Nowe zagrożenia upraw rolniczych $\mathrm{w}$ Polsce przez szkodniki. Prog. Plant Protection/Post. Ochr. Roślin 44 (1): 248-253. 
Plumb R.I. 1992. Barley yellow dwarf. p. 41-79. In: „Plant Diseases of International Importance". Vol. 1. "Diseases of Cereals and Pulses" (J. Kumer, S. Chavbe, eds.). Englewood Cliffs, New Jersey, USA, Prentice, 273 pp.

Power A.G., Seaman A.J., Gray S.M. 1991. Aphid transmission of barley yellow dwarf virus: inoculation access periods and epidemiological implications. Phytopathology 81: 545-548.

Robertson N.L., French R., Gray S.M. 1991. Use of group-specyfic primers and the polymerase chain reaction for the detection and identyfication of luteoviruses. J. Gen. Virol. 72: 1473-1477.

Ruszkowska M. 1988. Die Blattlaüse - Getreide Schädlinge - als eine Konsequenz der neuen Anbautechnologien. Tag.-Ber. Akad. Landwirtsch. Wiss. DDR, Berlin 271: 569-572.

Ruszkowska M. 1990a. Forecasting the abundance of Rhopalosiphum padi (L.) by means suction trap catch and meteorological data. Acta Phytopathol. Entomol. Hung. 25 (1-4): 447-451.

Ruszkowska M. 1990b. Możliwość wystąpienia różnych form biologicznych mszycy czeremchowo-zbożowej w Polsce. Zesz. Prob. Post. Nauk Rol. 392: 265-269.

Ruszkowska M. 1998. Aphids on winter cereals. p. 609-613. In: "Aphids in Natural and Managed Ecosystems" (J.M. Nieto Nafria, A.G. Dixon, eds.). Universidad de León, 688 pp.

Ruszkowska M. 2002. Przekształcenia cyklicznej partenogenezy mszycy Rhopalosiphum padi (L.) (Homoptera: Aphidoidae) - znaczenie zjawiska w adaptacji środowiskowej. Rozpr. Nauk. Inst. Ochr. Roślin, Poznań 8: 1-33.

Ruszkowska M. 2004. Modyfikacja progów szkodliwości i metody alternatywne w warunkach powstawania nowych form rozwojowych mszyc. Prog. Plant Protection/Post. Ochr. Roślin. 44 (1): 347-354.

Ruszkowska M. 2006. Uwarunkowania klimatyczne w rozprzestrzenianiu najważniejszych wektorów chorób wirusowych na zbożach w badanych regionach Polski. Prog. Plant Protection/Post. Ochr. Roślin 46 (1): 276-283.

Ruszkowska M. 2007a. Across the transformation life cycle of Rhopalosiphum padi (L.) (Homoptera: Aphidoidea): coevolution with temperature. Rozpr. Nauk. Inst. Ochr. Roślin, Poznań, $15,60 \mathrm{pp}$.

Ruszkowska M. 2007b. Mszyce na Oziminach. Inst. Ochr. Roślin, Poznań, 23 pp.

Ruszkowska M., Strażyński P. 2007. Profilaktyka w ochronie zbóż przed chorobą żółtej karłowatości jęczmienia. Prog. Plant Protection/Post. Ochr. Roślin. 47 (1): 363-366.

Strażyński P. 2010. Population structure of Rhopalosiphum padi (Linnaeus, 1758)/Hemiptera, Aphidoidea/ in Wielkopolska region in 2003-2008 in the context of winter cereals threat of BYDV expansion. p. 91-105. In: "Aphids and Other Homopterous Insects" (W. Goszczyński, A. Herczek, B. Leszczyński, G. Łabanowski, E. Podsiadło, R. Rakauskas, M. Ruszkowska, B. Wilkaniec, W. Wojciechowski, eds.). Lublin, $125 \mathrm{pp}$.

Strażyński P., Trzmiel K. 2008. Struktura jesiennych populacji mszycy czeremchowo-zbożowej (Rhopalosiphum padi L.) ocena realnego zagrożenia żółtą karłowatością jęczmienia w zróżnicowanych klimatycznie regionach Polski. Prog. Plant Protection/Post. Ochr. Roślin 48 (3): 804-807.

\section{POLISH SUMMARY \\ ZAGROŻENIE ZBÓŻ WIRUSAMI ŻÓŁTEJ KARŁOWATOŚCI JĘCZMIENIA PRZENOSZONYMI PRZEZ ANHOLOCYKLICZNE FORMY RHOPALOSIPHUM PADI L. W POLSCE W LATACH 2006-2008}

Wirusy żółtej karłowatości jęczmienia przenoszone są w sposób trwały głównie przez anholocykliczne formy mszycy czeremchowo-zbożowej (Rhopalosiphum padi L.). W Polsce gatunek ten dominuje na uprawach zbóż, a jego biologia związana jest ściśle z przebiegiem temperatur.

W latach 2006-2008 w celu określenia zasięgu występowania anholocyklicznych $R$. padi, a także oceny poziomu zagrożenia wirusami żółtej karłowatości jęczmienia, monitorowano 12 regionów Polski o zróżnicowanych warunkach temperaturowych. Obserwacje prowadzono pod kątem zasiedlania roślin przez anholocykliczne formy mszyc R. padi. Stwierdzono występowanie tych form na uprawach jęczmienia ozimego we wszystkich obserwowanych regionach, z wyjątkiem regionu podlaskiego.

W celu wykrywania trzech głównych sprawców żółtej karłowatości jęczmienia: Barley yellow dwarf virus-MAV (BYDV-MAV), Barley yellow dwarf virus-PAV (BYDV-PAV) i Cereal yellow dwarf virus-RPV (CYDV-RPV), próby roślin były poddane diagnostyce wirusologicznej. W 2007 roku przeprowadzono także badania na obecność wirusów żółtej karłowatości jęczmienia w mszycach żerujących na jęczmieniu ozimym. Wykazano, że najczęściej występującym wirusem był BYDV-PAV. Najwięcej mszyc - wektorów wirusów żółtej karłowatości jęczmienia, stwierdzono we wszystkich lokalizacjach regionu opolskiego, najcieplejszego regionu w Polsce. 